\title{
Physical and Organoleptic Qualities of Milk-Based Caramel with Variations in Addition of Pineapple Fruit (Ananas comosus (L) Merr.)
}

\author{
D. L. Rukmi ${ }^{*}$, M. N. A. Muslim ${ }^{1}$, E. C. Wulandari' ${ }^{2}$ S. Mulyani ${ }^{3}$, and A. M. Legowo ${ }^{3}$ \\ ${ }^{1}$ Department of Animal Science, Politeknik Negeri Jember \\ ${ }^{2}$ Faculty of Animal Science, Universitas Boyolali \\ ${ }^{3}$ Department of Food Technology, Faculty of Animal and Agricultural Sciences, \\ Diponegoro University \\ *Corresponding author: dyah.laksito@polije.ac.id
}

\begin{abstract}
The purpose of this study was to determine the physical and organoleptic qualities of milk-based caramel with variations in the use of pineapple (Ananas comosus (L) Merr.). The design of this study used a completely randomized design (CRD) with five treatments and four replications. The tested treatments include milk-based caramel, which was processed with pineapple juice at $\mathrm{T} 0=0 \% ; \mathrm{T} 1=5 \% ; \mathrm{T} 2=10 \% ; \mathrm{T} 3=15 \% ; \mathrm{T} 4=20 \%$. The research variables included physical quality testing consisting of water content and crude fiber content, further testing of texture, color, and panelists' preference as organoleptic parameters tested using sensory tests. The observations obtained will be processed using analysis of variance (ANOVA) with a level of 5\% and will be further tested using Duncan's Multiple Range Test (DMRT) if it shows a significant effect. Based on the results of analysis of variance (ANOVA), the variation in various treatments with the addition of pineapple fruit in the milk-based caramel processing showed a significant effect $(\mathrm{P}<0.05)$ on the physical quality of caramel (crude fiber content and water content) and organoleptic quality (texture, color), and preference) on milk-based caramel products. The percentage of crude fiber content is $0.35 \%-4.50 \%$; moisture content $10.15 \%-15.63 \%$; texture score is hard to not hard; colour score is light brown to brown and liking score is slightly like to like. The conclusion of this research was the addition of pineapple affects crude fiber content, milk caramel water content, texture, colour, and milk caramel preference.
\end{abstract}

Key words: Caramelized milk, pineapple, physical quality, organoleptic.

\section{INTRODUCTION}

The main product of dairy cattle is milk. Milk contains a variety of balanced nutrient content that plays an essential role for health for the human body. On the other hand, milk is also a potential medium for the growth of various kinds of bacteria that can cause damage to milk quality in terms of physical, chemical, and microbiological aspects (Hariono et al., 2020). In line with the many nutritional elements that are important for the body, milk is also a suitable medium for the growth of microorganisms, resulting in short shelf life of milk (Kustiawan \& Rukmi, 2018). Milk is very easy to lose quality and get damaged if it is not handled and processed correctly. Thermal processing, fermentation and dehydration are the main processing techniques to store milk (Amit et al., 2017). One alternative to maintaining dairy products' shelf life and usability is to process milk into caramel.

Milk caramel is a snack product made from milk popular among the public but does not contain fiber. Meanwhile, the minister of Health RI No. 28 of 2019 recommends the minimum fiber consumption of 20-37 g/person/day
(Kemenkes RI, 2019). One of the solutions offered is adding fruit as a source of fiber. Variations in the addition of various fruits that grow in Indonesia can provide a specific aroma and color to improve the appearance of the resulting milk caramel product (Marlina et al., 2019). One of the fruits added to the milk caramel processing is pineapple. Pineapple is a tropical fruit ranked third in the world as a preferred fruit because of its characteristic aroma and taste, which is well accepted by the public. Pineapple is also good for the digestive system and helps maintain ideal body weight with balanced nutrition. Processed pineapple products are consumed worldwide, and the processing industry is trying to use new technologies to maintain the nutritional quality of pineapples (Chaudhary et al., 2019). According to the data, the nutrient content of fresh pineapple calculated per $100 \mathrm{~g}$, or what is commonly referred to as the Edible Weight $53 \%$ is energy $40 \mathrm{cal}$; carbohydrates $9.9 \mathrm{~g}$; fiber $0.6 \mathrm{~g}$; $0.6 \mathrm{~g}$ protein; ash $0.3 \mathrm{~g}$; fat $0.3 \mathrm{~g}$; thiamin $0.06 \mathrm{~g}$; vitamin C $22 \mathrm{mg}$; and carotene $17 \mathrm{mcg}$ (Directorate of the Department of Nutrition, 2017). 
The process of processing milk caramel is known as caramelization. Caramelization is a sugar degradation reaction at high temperatures, which results in the final product being a brown nitrogen-free polymer. Caramelization usually occurs in ingredients or food products that contain high carbohydrates or sugar (Subroto \& Iman Firtian, 2020). The caramelization process is through an evaporation mechanism which results in the evaporation of the water content in the sugar. Fragmentation in these volatile compounds contributes to the resulting caramel flavor (Kaur et al., 2018). Caramelization can be accelerated in the presence of carboxylic acids and their salts, phosphates, and metal ions. Still, even when so catalyzed, the energy requirements exceed the reactions of sugar amines (Fuquay et al., 2011). Caramelization products vary in chemical and physical properties and their constituents depending on temperature, $\mathrm{pH}$, and duration of heating (Gogus et al., 2010).

The mechanism of the caramelization reaction involves several steps, starting with the enolization of sugars such as glucose and fructose, producing 1,2-enol compounds through a heating process. If under acidic conditions, this reaction can occur more quickly. The next step 1,2-enol can undergo two possibilities, namely, dehydration or fission reactions. In the dehydration reaction, the compound 5hydroxymethyl-2-furaldehyde, which is one of the precursors of the brown pigment, is produced. The dehydration reaction will occur on heating a sugar solution under acidic conditions and reaching a maximum at a $\mathrm{pH}$ below 3; This reaction can be called acid degradation. In the fission stage, 1,2enol is decomposed to produce compounds.

\section{MATERIALS AND METHODS}

\section{Milk caramel ingredients}

Making milk caramel consists of several stages: first heating, mixing, heating until smooth, printing, cutting, and packaging. The ingredients needed to manufacture milk caramel in this study were milk, pineapple, gelatin, sugar, and margarine. Pineapple will work as a reductant, and enadiol and pyruvaldehyde, also precursors of the brown pigment. The fission process occurs under alkaline conditions of the sugar pack but can also occur under weak acid conditions. The fission process will increase rapidly as the $\mathrm{pH}$ of the system increases. This process is also called alkaline degradation reaction, and the final step is polymerization formation and condensation for the formation of brown pigment (Sengar \& Sharma, 2014). For treatment must be prepared in advance. Pineapple fruit is selected good, fresh, and ripe, then peeled and removed the eye flesh. Washed and shaved until wholly crushed and then weighed according to the treatment. The flow chart for processing milk caramel with the addition of pineapple is presented in Figure 1.

Each treatment unit used $125 \mathrm{~g}$ of sugar, $5 \mathrm{~g}$ of margarine, $3 \mathrm{~g}$ of gelatin, and pineapple fruit were given according to the predetermined concentration variations, namely $0 \%$ (T0), 5\% (T1), $10 \%$ (T2), 15\% (T3) and 20\% (T4). The amount of milk adjusts to the volume of $700 \mathrm{~g}$ per experimental unit. It is known that $\mathrm{T} 0$ (without the addition of pineapple) uses $567 \mathrm{~g}$ of milk, $\mathrm{T} 1 \mathrm{uses}$ $35 \mathrm{~g}$ of pineapple and $532 \mathrm{~g}$ of milk, T2 uses $70 \mathrm{~g}$ of pineapple and $497 \mathrm{~g}$ of milk, T3 uses $105 \mathrm{~g}$ of pineapple and milk as much as $464 \mathrm{~g}$ and T4 using pineapple fruit as much as $140 \mathrm{~g}$ and using milk as much as $462 \mathrm{~g}$.

The process of processing caramel with milk-based ingredients begins with heating the milk in a non-stick pan using a small flame. Previously, the non-stick pan used had been coated with margarine on the entire surface of the pan. Then the milk is stirred slowly at a constant speed until the volume of milk decreases slowly. Next, add the sugar little by little, then the gelatin, and the last is the addition of the pineapple that has been pulverized until the dough is evenly mixed and thickens. After reaching the desired consistency, stop the heating and stirring process. To ensure whether the caramel dough is ready to be printed in the pan, we must manually check by dripping a teaspoon of dough into a bowl filled with cold water. If a thick circle is formed and does not break, the dough is ready to be molded in the pan. The process is repeated under the treatment and replications that have been determined.

\section{Crude fiber content test (Latimer Jr., 2019)}

Firstly, $1 \mathrm{~g}$ of the sample was weighed and put it in a beaker. Then, $50 \mathrm{ml}$ of $0.3 \mathrm{~N}$ sulfuric acid was added and cooked for 30 minutes, followed by adding of $25 \mathrm{ml}$ of $1.5 \mathrm{~N}$ sodium hydroxide and further cooked again for the same time, that is 30 minutes. Furthermore, the solution was filtered using Whatman paper which had previously been dried in an oven at a temperature of $105-110^{\circ} \mathrm{C}$ for 1 hour and allowed to stand in a desiccator for \pm 15 minutes, then continued with the first weighing (a). The next 


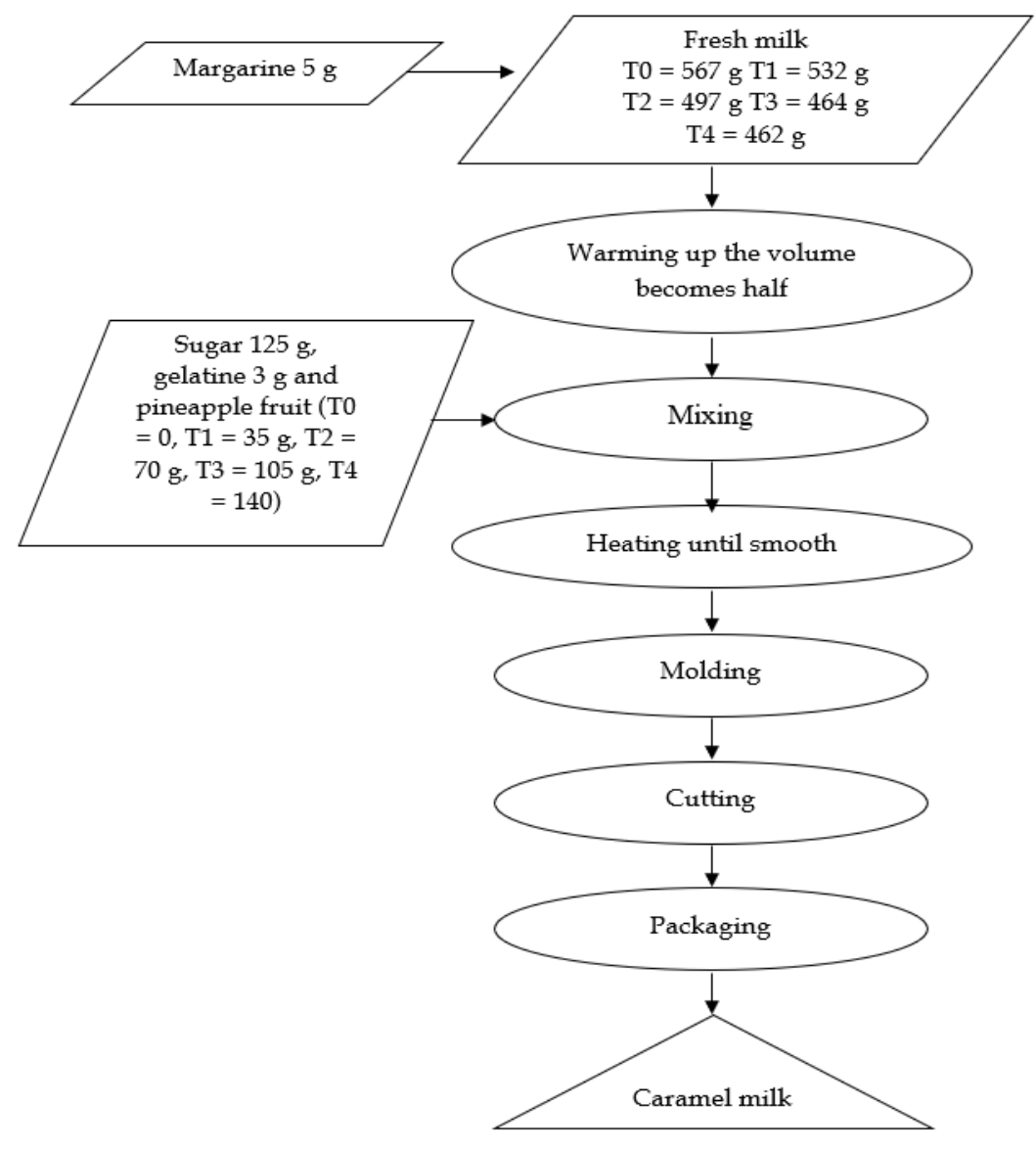

Figure 1. Flowchart of the milk-based caramel processing process with variations in the addition of various concentration levels with the addition of pineapple.

process is to do the washing successively with 50 $\mathrm{ml}$ of boiling water, $50 \mathrm{ml}$ of $0.3 \mathrm{~N}$ sulfuric acid, $50 \mathrm{ml}$ of hot water, and $25 \mathrm{ml}$ of acetone.

Then Whatman paper and its contents were put in a porcelain dish and oven at a temperature of $105-110^{\circ} \mathrm{C}$ until a constant weight was reached and then put in a desiccator for 15 minutes, followed by a second weighing (y). The last process is put in a kiln set at $600^{\circ} \mathrm{C}$ for \pm 6 hours. If it is reached, the sample is cooled in a desiccator for \pm 15 minutes and the final weighing (z) is carried out.

The formula for calculating crude fiber content is as follows:

\section{Coarse Fiber $=\frac{\mathrm{y}-\mathrm{z}-\mathrm{a}}{\mathrm{x}} \quad \mathrm{x} 100 \%$}

Note:

$\mathrm{x}=$ sample weight

$y=$ sample weight + whatman filter paper + cup after oven

$\mathrm{z}=$ weight of sample + cup after kiln

$\mathrm{a}=$ weight of whatman paper

\section{Water content testing (Latimer Jr., 2019)}

The porcelain cup used in the water content test was first dried in an oven set at a temperature of $105-110^{\circ} \mathrm{C}$ for 60 minutes and put in a desiccator for 15 minutes and then weighed as $\mathrm{x}$ weight. A total of product samples with a weight of $y$ were put into a porcelain cup and then the drying process was carried out using an oven for 4 hours at a temperature of $105-110^{\circ} \mathrm{C}$ then put in a desiccator for 15 minutes weighed as a weight of $\mathrm{z}$. This drying process was carried out for $3 \times 60$ minutes until a constant weight was reached or the weight was no longer changing with a maximum difference in weight of $0.2 \mathrm{mg}$. The formula for calculating water content is as follows:

$$
\text { Water Content }=\frac{x+y-z}{y} \times 100 \%
$$

Note :

$\mathrm{x}=$ weight of porcelain dish after baking (g)

$\mathrm{y}=$ sample weight $(\mathrm{g})$

$\mathrm{z}=$ weight of porcelain cup + sample after oven $(\mathrm{g})$ 


\section{Texture, color, and preference testing}

Texture testing was carried out using the sensory test method with the help of 25 moderately trained panelists. The panelist criteria used were male and female students aged around 20-25 years. Panelists were given the task of giving an assessment score on the texture, color, and preference for the caramel product served. In texture testing, there is a score of 1 for very hard texture, 2 for hard texture, 3 for slightly hard texture, and 4 for not hard texture. In the color test, there is a score of 1 for yellowish-brown, a score of 2 for light brown, a score of 3 for brown, and a score of 4 for dark brown. Furthermore, in the liking test, the panelists were asked to give a score of 1 if the caramel served was not liked, a score of 2 if they liked it somewhat, a score of 3 if they liked it, and a score of 4 if they liked it very much.

\section{Research design}

The research design used to test milk caramel's physical quality, including crude fiber content and moisture content, in this study was a Completely Randomized Design (CRD) with T0, $\mathrm{T} 1, \mathrm{~T} 2, \mathrm{~T} 3$, and T4 as treatments and with four replications while for organoleptic quality testing. Covering texture, color and preferences using 25 moderately trained panelists. The treatment can be written as follows:

$\mathrm{T} 0=$ caramel made from milk without the addition of pineapple

$\mathrm{T} 1$ = caramel made from milk with the addition of $5 \%$ pineapple $\mathrm{w} / \mathrm{w}$

$\mathrm{T} 2=$ caramel made from milk with the addition of $10 \%$ pineapple $\mathrm{w} / \mathrm{w}$

$\mathrm{T} 3=$ milk-based caramel with the addition of $15 \%$ pineapple $\mathrm{w} / \mathrm{w}$

$\mathrm{T} 4$ = caramel made from milk with the addition of $20 \%$ pineapple $\mathrm{w} / \mathrm{w}$

Table 1. Sensory test parameters of milk-based caramel with the addition of pineapple

\begin{tabular}{lll}
\hline & \multicolumn{1}{c}{ Sensory Test Parameters } \\
\hline Texture Level & Colour Level & Levels of pleasure \\
\hline $1=$ very hard & $1=$ yellowish-brown & $1=$ Do not like \\
$2=$ hard & $2=$ light brown & $2=$ Rather like \\
$3=$ rather hard & $3=$ brown & $3=$ Like \\
$4=$ not hard & $4=$ dark brown & $4=$ Very much like \\
\hline
\end{tabular}

\section{Data Analysis}

The results of testing the crude fiber content, water content, texture, color, and preference of milk-based caramel were processed using an analysis of variance. Suppose it is known that there is a significant effect, then for testing the crude fiber content and water content. In that case, further tests are carried out using Duncan's Multiple Distance Test (DMRT) to determine the difference between treatments at the $5 \%$ level than for testing texture, color, and preference level, further tested using the Honest Significant Difference Test (BNJ).

\section{RESULTS AND DISCUSSION}

\section{Crude Fiber Content and Caramel Water Content}

Pineapple is a fruit that is often found in tropical countries. Pineapple is a fruit often found in tropical countries with a specific and distinctive taste and aroma (Yulia et al., 2020). Dietary fiber is a plant constituent that belongs to the carbohydrate group with the characteristics of absorbing more water. This dietary fiber provides many uses for humans. These uses include improving digestion and preventing cancer in the digestive tract, lowering blood glucose levels, can be used as a prebiotic, controlling obesity and obesity, and can reduce blood cholesterol (Fairudz \& Nisa, 2015). Dietary fiber is classified into two groups, namely soluble dietary fiber and insoluble dietary fiber (Fuller et al., 2016). Water-soluble dietary fiber can survive in the digestive tract of living things and provide a longer feeling of fullness, prolong the absorption of glucose into the blood, and reduce cholesterol content in the blood. Meanwhile, food fiber that is difficult to dissolve in water is a dietary fiber that can shorten the process of food flow in the intestines, increase the volume of feces, and anticipate the occurrence of colonization cancer. 
Table 2. The average crude fiber and water content of milk-based caramel with the addition of pineapple.

\begin{tabular}{ccc}
\hline Treatment & Crude fiber content & Water Content \\
\hline T0 & $0,35 \pm 0,81^{\mathrm{c}}$ & $10,15 \pm 0,03^{\mathrm{c}}$ \\
T1 & $3,14 \pm 1,66^{\mathrm{b}}$ & $10,89 \pm 0,29^{\mathrm{bc}}$ \\
T2 & $3,37 \pm 0,72^{\mathrm{b}}$ & $11,60 \pm 0,16^{\mathrm{bc}}$ \\
T3 & $4,34 \pm 1,63^{\mathrm{a}}$ & $12,98 \pm 0,20^{\mathrm{b}}$ \\
T4 & $4,50 \pm 2,16^{\mathrm{a}}$ & $15,63 \pm 0,35^{\mathrm{a}}$ \\
\hline
\end{tabular}

Notes: $\mathrm{T} 0=$ milk-based caramel with the addition of pineapple $(\mathrm{w} / \mathrm{w}) ; \mathrm{T} 1=$ caramel made from milk with the addition of 5\% pineapple $(\mathrm{w} / \mathrm{w}) ; \mathrm{T} 2=$ milk-based caramel with $10 \%$ pineapple added $(\mathrm{w} / \mathrm{w}) ; \mathrm{T} 3=$ milkbased caramel with an additional $15 \%$ pineapple $(\mathrm{w} / \mathrm{w})$; T4=milk-based caramel with the addition of $20 \%$ pineapple (w/w)

a,b,bc,c Different superscripts in the same line showed significant differences $(\mathrm{P}<0.05)$

Based on the information in Table 2, it indicates that the addition of pineapple in the milk-based caramel processing can significantly increase the crude fiber content of the resulting product. In addition, although there was an increase in the crude fiber content of caramelized milk due to the addition of pineapple percentage. The same trend occurred in the results of the same caramel crude fiber, where the results of $\mathrm{T} 1$ and $\mathrm{T} 2, \mathrm{~T} 3$ and $\mathrm{T} 4$ had the same letter notation, although there was a difference in the addition of pineapple as much as $5 \%$ in each treatment. There may be an effect of changing dietary fiber into caramel, so that the caramel crystallization process is faster. One of the dietary fiber in pineapple is pectin. The higher the concentration of pineapple added, it will be followed by an increase in the pectin content. This is because the gelatinization process influences the gel formation in the caramel process at a certain temperature and the acid-water-pectin balance (Nilasari et al, 2017). In this study, crude fiber turned into caramel is counted as crude fat in proximate analysis because it has undergone a cooking process.

The addition of pineapple to the increasing treatment will affect the water content in milk caramel. The water content of pineapple reaches $90 \%$, the increase in the amount of water content in the caramel is in line with the amount of crude fiber content in the milk caramel (Table 2). This is related to one of the benefits of crude fiber, the main food ingredient in its ability to bind water. In addition to binding water, crude fiber also can bind cellulose and pectin. The water content that is too little in results in the hardness of the texture obtained in caramel products; on the contrary, if the water content is too excessive, it will cause the caramel texture to become mushy. The analysis of crude fiber content and water content in milk caramel obtained consistent results; the higher the crude fiber content in caramel, the more water content in caramel increased. This is by the opinion (Praseptiangga et al, 2016) that the amount of dietary fiber content will be accompanied by the more significant the ability of a material to bind water.

\section{Pineapple Caramel Organoleptic Quality}

The taste of food determines the consumer's acceptance of a product. The taste of food involves various sensory attributes in the human taste. The human sense of taste works by combining taste, smell, and experience from the person concerned. The supporting elements of taste and quality in a product are the integration of the constituent ingredients with the composition that has been formulated. (Pramitasari, 2010). The texture of a product is one of the awards that consumers can recognize for the first time through the five senses (Sari \& Yohana, 2015). The heating process and the properties of the constituent materials are closely related to the texture (tenderness) of caramel (Wulandari et al., 2014). Caramel with a soft texture is related to its ability to absorb water (hygroscopic). Consumers favor caramel products that generally have a soft and chewy texture (Bakar \& Usmiati, 2009). The presence of glucose syrup, sucrose, and additional fruit juice in the composition also influences the formation of the texture of the resulting caramel product. Glucose syrup serves as a caramel surface protector. It also has hygroscopic properties, which can help get the desired caramel texture. 
Table 3. Organoleptic test results (texture, color, preference)

\begin{tabular}{cccccc}
\hline Parameter & \multicolumn{5}{c}{ Treatment } \\
\cline { 2 - 6 } & $\mathrm{T} 0$ & $\mathrm{~T} 1$ & $\mathrm{~T} 2$ & $\mathrm{~T} 3$ & $\mathrm{~T} 4$ \\
\hline Texture & $2.80 \pm 0.63^{\mathrm{b}}$ & $2.68 \pm 0.44^{\mathrm{b}}$ & $3.68 \pm 0.59^{\mathrm{a}}$ & $3.80 \pm 0.72^{\mathrm{a}}$ & $3.84 \pm 0.88^{\mathrm{a}}$ \\
Colour & $2.64 \pm 0.16^{\mathrm{a}}$ & $2.48 \pm 0.16^{\mathrm{ab}}$ & $2.28 \pm 0.10^{\mathrm{abc}}$ & $2.24 \pm 0.05^{\mathrm{bc}}$ & $2.20 \pm 0.04^{\mathrm{c}}$ \\
Kesukaan & $2.48 \pm 0.27^{\mathrm{b}}$ & $2.56 \pm 0.38^{\mathrm{bc}}$ & $3.36 \pm 0.21^{\mathrm{a}}$ & $2.56 \pm 0.26^{\mathrm{b}}$ & $2.88 \pm 0.31^{\mathrm{ab}}$ \\
\hline
\end{tabular}

Notes: T0=milk-based caramel with the addition of pineapple $(\mathrm{w} / \mathrm{w})$; $\mathrm{T} 1=$ caramel made from milk with the addition of $5 \%$ pineapple $(\mathrm{w} / \mathrm{w})$; T2=milk-based caramel with $10 \%$ pineapple added $(\mathrm{w} / \mathrm{w})$; T3=milkbased caramel with an additional $15 \%$ pineapple $(\mathrm{w} / \mathrm{w})$; T4=milk-based caramel with the addition of $20 \%$ pineapple $(\mathrm{w} / \mathrm{w})$

a,b,bc,c Different superscripts in the same line showed significant differences $(\mathrm{P}<0.05)$

The results of the texture test on milk caramel at treatment $\mathrm{T} 0$ were the same as the textures at $\mathrm{T} 1, \mathrm{~T} 2, \mathrm{~T} 3$ and $\mathrm{T} 4$ also had similarities but differed from $\mathrm{T} 0$ and $\mathrm{T} 1$. This shows that the additional level with a maximum percentage of $5 \%$ does not change the caramel structure, while more than $5 \%$ can change the caramel structure. This is influenced by the level of addition of pineapple, which can change caramel's water content. This change in texture corresponds to the caramel moisture content (Table 3). The highwater content in an ingredient causes the caramel texture formed to be soft. Caramel classification based on water content consists of hard $(6 \%)$, medium $(8 \%)$, and soft (10\% water content) (Buckle et al., 2013). Caramelization is a nonenzymatic browning reaction of sugar that gives it a caramel-like taste during high-temperature food processing.

Various successive and parallel reactions can occur during the heating of sugars. The quantitative distribution of intermediates and products depends on $\mathrm{pH}$, water activity, redox potential, and food structure. The taste and color of caramel are characteristic results of thermal processing from a food quality point of view and can be controlled to achieve the desired properties. The processing of milk-based caramel begins with the heating process of milk. Heating milk at high temperatures will affect the fat content, viscosity, flavor, and odor. Flavor and odor in milk will change the protein and lactose content in milk. Meanwhile, the viscosity will decrease when milk is heated at pasteurization temperature and will increase when milk boils. Heating milk at the same temperature causes the Maillard reaction, where a brown color is formed as a result of the reaction between sugar and amine groups (proteins, amino acids, peptides) (Rini, 2016).

Processing caramel made from milk with the addition of pineapple, the greater the percentage of pineapple will produce a caramel color closer to light brown. These results are due to the influence of pineapple fruit which causes more and more bright colors in the caramel product that is formed. The yellow color of pineapples is formed by the content of xanthophyll pigments, consisting of several types, including -cryptoxanthin, lutein, and zeaxanthin. The content of -carotene in pineapple reaches 17 ug. Pigments belonging to the xanthophyll group are also included in the carotenoid group. The content of the carotenoid pigment in the fruit is getting bigger, marked by a green change in the fruit to yellow when ripe (Putri et al., 2018). In addition, the caramel color formed can also be influenced by the pineapple's water content, which reaches $90 \%$. The high-water content of the pineapple can inhibit the caramelization process, which in turn will affect the caramel color of the milk. The color of food is the first concern of humans when they will enjoy food. Therefore, the caramel color that attracts consumers' attention will become a natural magnet before considering the content of other important nutrients in the selection of ready-to-eat food products.

The organoleptic test scores for the level of preference for milk caramel ranged from 1 to 4 , with the category of dislike to very much like. Based on statistical analysis, it can be seen that the concentration of pineapple fruit $10 \%$ (T2) has a significant effect $(\mathrm{P}<0.05)$ on the level of preference for milk caramel. This phenomenon is caused by the texture content of milk caramel at $\mathrm{T} 2$ is the best, which has a score of 3.68 with a slightly hard to not hard (soft) category. At $0 \%$ concentration of pineapple (T0), it showed a decrease with a score of 2.48 with a hard to slightly hard texture category.

\section{CONCLUSION}

The conclusion of the reseach was additional pineapple variations significantly affect crude fiber content and water content in milk- 
based caramel processing. The high-water content results in a softer texture, lighter color, and an increased preference for milk caramel. The ideal pineapple content to add to milk caramel is $10 \%$.

\section{REFERENCES}

Amit, S. K., M. M. Uddin, R. Rahman, S. M. R. Islam, \& M. S. Khan. 2017. A review on mechanisms and commercial aspects of food preservation and processing. Agriculture and Food Security, 6(1), 1-22. https://doi.org/10.1186/s40066-017-01308

Bakar, A., \& S. Usmiati. 2009. Teknologi Pengolahan Susu. Balai Besar Penelitian dan Pengembangan Pascapanen Pertanian. Bogor.

Buckle, K. A., R. Edwards, G. Fleet, M. Wootton, H. Purnomo, \& Ardiono. 2013. Ilmu Pangan. Universitas Indonesia.

Chaudhary, V., V. Kumar, \& K. Singh, 2019. Pineapple (Ananas cosmosus) product processing: A review. Journal of Pharmacognosy and Phytochemistry, 8(3), 4642-4652.

Direktorat Departemen Gizi, R. I. 2017. Pedoman Metode Melengkapi Nilai Gizi Bahan Makanan Pada Tabel Komposisi Pangan Indonesia (Imputated and Borrowed Values). Kementrian Kesehatan RI, 1-43.

Fairudz, A., \& K. Nisa. 2015. Pengaruh Serat Pangan Terhadap Kadar Kolesterol Penderita Overweight. Jurnal Majority, 4(8), 121-126.

Fuller, S., E. Beck, H. Salman, \& L. Tapsell. 2016. New Horizons for the Study of Dietary Fiber and Health: A Review. Plant Foods for Human Nutrition, 71(1), 1-12. https://doi.org/10.1007/s11130-016-05296

Fuquay, J. W., P. F. Fox, , \& P. L. H. McSweeney. 2011. Encyclopedia of Dairy Sciences (J. W. Fuquay, P. F. Fox, \& P. L. H. McSweeney (ed.); Second Edi). Elsevier Science.

Gogus, F., S. Fadiloglu, , \& C. Soysal. 2010. Biological Oxidations: Enzymatic and Nonenzymatic Browning Reactions and Control Mechanisms. In F. Yildiz (Ed.),
Advances in Food Biochemistry (hal. 522). CRC Press.

Hariono, B., R. Wijaya, , \& S. Anwar. 2020. Comparative study on the physical characteristics of goat milk pasteurization through serial and circulation systems of ultraviolet method. Journal of Physics: Conference Series, 1450 (1). https://doi.org/10.1088/17426596/1450/1/012056

Kaur, S., S. Kumar, \& R. Kaur. 2018. Physicochemical and Organoleptic Properties of Caramel Coated Chhana Confection Incorporated with Mango and Pineapple Powder. International Journal of Current Microbiology and Applied Sciences, $\quad 7(08), \quad 3110-3120$. https://doi.org/10.20546/ijcmas.2018.708. 332

Kemenkes RI. 2019. Angka Kecukupan Gizi Mayarakat Indonesia. Menteri Kesehatan Republik Indonesia Peraturan Menteri Kesehatan Republik Indonesia, Nomor 65(879), 2004-2006.

Kustiawan, E., \& D. L. Rukmi. 2018. Teknologi Hasil Ternak: Prinsip, Prosedur, dan Teknologi Pengolahan Susu (N. Martina \& M. Fauzy (ed.). PNJ Press.

Latimer Jr., G. W. 2019. The Official Methods of Analysis of AOAC International (G. W. Latimer Jr. (ed.); 21st Editi). AOAC International.

Marlina, M., M. Wijaya, \& K. Kadirman, 2019. Pengaruh Penambahan Buah Naga Merah (Hylocereus Polyrhizus) Terhadap Mutu Permen Karamel Susu. Jurnal Pendidikan Teknologi Pertanian, 5(1), 85. https://doi.org/10.26858/jptp.v5i1.8199

Nilasari, O. W., W. H. Susanto, \& J. M. Maligan. 2017. Pengaruh Suhu Dan Lama Pemasakan Terhadap Karakteristik Lempok Labu Kuning (Waluh). Jurnal Pangan dan Argoindustri, 5(3), 15-26.

Pramitasari, D. 2010. Penambahan ekstrak jahe (Zingiber officinale rosc.) dalam pembuatan susu kedelai bubuk instan dengan metode spray drying: komposisi kimia, sifat sensoris dan aktivitas antioksidan. Universitas Sebelas Maret. 
Praseptiangga, D., T. P. Aviany, \& N. H. R. Parnanto, 2016. Pengaruh Penambahan Gum Arab Terhadap Karakteristik Fisikokimia Dan Sensoris Fruit Leather Nangka (Artocarpus heterophyllus). Jurnal Teknologi Hasil Pertanian, 9(1), 71-83. https://doi.org/10.20961/jthp.v9i2.12858

Putri, U. M., R. S. Ningrum, \& W. Lindasari. 2018. Analisis Beta Karoten Pada Nanas (Ananas Comosus (L.) Merr) Varietas Queen Dan Cayenne Menggunakan Spektrofotometri. Prosiding Seminar Nasional Sains, Teknologi dan Analisis Ke1, 212-218.

Rini, H. 2016. Reaksi Maillard - Pembentukan Citarasa dan Warna pada Produk Pangan. Lambung Mangkurat University Press.

Sari, K. I., \& W. Yohana. 2015. Tekstur makanan: sebuah bagian dari food properties yang terlupakan dalam memelihara fungsi kognisi? (Food texture : a part of the food properties that ignorable for maintaining cognitive function?). Makassar Dent J, 4(6), 184-189.
Sengar, G., \& H. K. Sharma. 2014. Food caramels: a review. Journal of Food Science and Technology, 51(9), 16861696. https://doi.org/10.1007/s13197-0120633-Z

Subroto, E., \& R. I. Firtian. 2020. Characteristics, Mechanism, and Applications of The Caramelization and Maillard Reaction Product-A Review. International Journal of Advanced Science and Technology, 29(6), 5078-5086.

Wulandari, B., D. Ishartani, \& D. R. Afandi. 2014. Penggunaan Pemanis Rendah Kalori Pada Pembuatan Velva Ubi Jalar Oranye (Ipomoea batatas L.). Jurnal Teknosains Pangan, 3(3), 41-48.

Yulia, R., N. Handayani, \& J. Juliani. 2020. Pengaruh Buah Kundur (Benincasa hispida) dan Buah Nanas (Ananas comosus L. Merr) Rasio Serta Konsentrasi Gula Terhadap Mutu Fruit Leather. Jurnal Serambi Engineering, 5(2), 995-1002. https://doi.org/10.32672/jse.v5i2.1927 